\title{
Expression of concern: subfunctionalization reduces the fitness cost of gene duplication in humans by buffering dosage imbalances
}

\author{
Maria K Kowalczuk*, Shreeya Nanda and Elizabeth C Moylan
}

\begin{abstract}
After publication of this article (Fernandez et al., BMC Genomics 2011, 12:604) it was brought to the Editors' attention that the data generated by the first author, Ariel Fernandez, seemed anomalous. One of the author's institutions found that the data were not reproducible from the described methods, but an investigation by the author's other institution did not find the data or their interpretation suspicious. Given the conflicting conclusions of these investigations, the Editors advise the readers to interpret the data with due caution. We apologize to all affected parties.
\end{abstract}

\section{Comment on}

Ariel Fernandez, Yun-Huei Tzeng and Sze-Bi Hsu. Subfunctionalization reduces the fitness cost of gene duplication in humans by buffering dosage imbalances. $B M C$ Genomics 2011, 12:604. doi:10.1186/1471-2164-12-604. URL http://www.biomedcentral.com/1471-2164/12/604.

Received: 18 March 2013 Accepted: 20 March 2013

Published: 17 April 2013

\section{References}

1. Fernandez A, Tzeng YH, Sze-Bi Hsu SB: Subfunctionalization reduces the fitness cost of gene duplication in humans by buffering dosage imbalances. BMC Genomics 2011, 12:604.

\footnotetext{
* Correspondence: Maria.Kowalczuk@biomedcentral.com

The authors are the Biology Editors for BioMed Central. BioMed Central, 236 Gray's Inn Road, London WC1X 8HB, United Kingdom
}

Submit your next manuscript to BioMed Central and take full advantage of:

- Convenient online submission

- Thorough peer review

- No space constraints or color figure charges

- Immediate publication on acceptance

- Inclusion in PubMed, CAS, Scopus and Google Scholar

- Research which is freely available for redistribution

\section{Biomed Central}

(c) 2013 Kowalczuk et al.; licensee BioMed Central Ltd. This is an Open Access article distributed under the terms of the Creative Commons Attribution License (http://creativecommons.org/licenses/by/2.0), which permits unrestricted use, distribution, and reproduction in any medium, provided the original work is properly cited. 